\title{
Harmonization of Private law on a Global Level
}

Citation for published version (APA):

Herings, P. J. J., \& Kanning, A. J. (2008). Harmonization of Private law on a Global Level. International Review of Law and Economics, 28, 256-262. https://doi.org/10.1016/j.irle.2008.07.003

Document status and date:

Published: 01/01/2008

DOI:

10.1016/j.irle.2008.07.003

Document Version:

Publisher's PDF, also known as Version of record

Document license:

Taverne

\section{Please check the document version of this publication:}

- A submitted manuscript is the version of the article upon submission and before peer-review. There can be important differences between the submitted version and the official published version of record.

People interested in the research are advised to contact the author for the final version of the publication, or visit the DOI to the publisher's website.

- The final author version and the galley proof are versions of the publication after peer review.

- The final published version features the final layout of the paper including the volume, issue and page numbers.

Link to publication

\footnotetext{
General rights rights.

- You may freely distribute the URL identifying the publication in the public portal. please follow below link for the End User Agreement:

www.umlib.nl/taverne-license

Take down policy

If you believe that this document breaches copyright please contact us at:

repository@maastrichtuniversity.nl

providing details and we will investigate your claim.
}

Copyright and moral rights for the publications made accessible in the public portal are retained by the authors and/or other copyright owners and it is a condition of accessing publications that users recognise and abide by the legal requirements associated with these

- Users may download and print one copy of any publication from the public portal for the purpose of private study or research.

- You may not further distribute the material or use it for any profit-making activity or commercial gain

If the publication is distributed under the terms of Article $25 \mathrm{fa}$ of the Dutch Copyright Act, indicated by the "Taverne" license above, 


\title{
Harmonization of private law on a global level
}

\author{
P. Jean-Jacques Herings ${ }^{a, *, 1}$, Arnald J. Kanning \\ a Department of Economics, Maastricht University, P.O. Box 616, 6200 MD Maastricht, The Netherlands
}

\section{A R T I C L E I N F O}

\section{JEL classification:}

K00

D61

Keywords:

Unification

Harmonization

Private law

Economic interdependencies

Game theory

\begin{abstract}
A B S T R A C T
The Vienna Sales Convention (1980) follows in large measure the American Uniform Commercial Code: Article 2 on Sales. Is this to imply that the Contracting States to the Vienna Sales Convention really prefer American sales law? This paper answers this question in the negative, and argues instead that the United States' economic leverage with other countries is the key factor influencing developments pertaining to private law on a global level.

We explain why it may be useful to harmonize rules of private law on a global level and which rules should be chosen for a uniform law. We show that the choice between two legal arrangements may lead to a coordination problem. Next we argue that the coordination problem is solved in favor of the jurisdiction whose economy is less dependent upon the economies of other jurisdictions than the other way around. We use our model to discuss the harmonization of sales law on a global level in the twentieth century.
\end{abstract}

(c) 2008 Elsevier Inc. All rights reserved.

\section{Introduction}

The unification and harmonization ${ }^{2}$ of private law on a global level is a theme that receives increasing attention from legal scholars. For example, in 2002, the International Institute for the Unification of Private Law (UNIDROIT) held a congress on "Worldwide Harmonisation of Private Law and Regional Economic Integration". ${ }^{3}$ It is the aim of this paper to offer an economic perspective on the theme. Comparative legal scholars have hitherto neglected to include information on 'economic interdependencies' between separate jurisdictions into their studies of the globalization of private law. This is rather unfortunate because comparative studies of law, welcome as they are, for the most part only uncover similarities and discrepancies in the private law of separate jurisdictions.

By combining information on economic interdependencies between separate jurisdictions with the fruits of comparative legal scholarship in the field of private law we obtain new insights into the question why it may be useful to harmonize rules of private law on a global level and the question which rules should be cho-

\footnotetext{
* Corresponding author.

E-mail address: P.Herings@algec.unimaas.nl (P. Jean-Jacques Herings)

1 The author would like to thank the Netherlands Organisation for Scientific Research (NWO) for financial support.

2 The term 'harmonization' will be used throughout the paper to encompass all forms of approximation of laws, including unification.

3 The interested reader might refer to the Acts of the Congress that appeared in the Spring 2003 issue of the Uniform Law Review, with contributions by Basedow, Farnsworth, Schlechtriem, and many other legal scholars.
}

sen for a uniform law. This is for two reasons. Comparative legal research cannot provide a conclusive answer to the question of whether to harmonize (parts of) private law on a global level. Nor can comparative legal research provide a conclusive answer to the question of which legal rules to include into uniform private laws. To answer both questions, complementary information on economic interdependencies between separate jurisdictions is indispensable.

The point is that the extent to which private law harmonization can stimulate inter-jurisdictional economic activity might influence the extent to which separate jurisdictions are willing to harmonize their domestically defined private law. When harmonization of a particular branch of private law is unlikely to stimulate inter-jurisdictional economic activity, the willingness of separate jurisdictions to unify this branch of private law might be limited.

Furthermore, upon a decision to harmonize a particular branch of private law, separate jurisdictions still have to ponder over the issue of which legal rules to include into the uniform private law. Here, information on economic interdependencies between separate jurisdictions is indispensable once again. Although a jurisdiction might prefer its own legal rules to any other legal rules, a jurisdiction might nonetheless have an interest in placing the legal rules of another jurisdiction into uniform private laws rather than any other legal rules. For, in so doing, this jurisdiction might boost its own economic growth by stimulating economic activity with the other jurisdiction. We will argue that the legal arrangements of the jurisdiction whose economy is less dependent upon the economies of the other jurisdictions than the other way around are the ones most likely to be included into the uniform private law. To keep the 
length of the paper in check, the analysis will be confined to contract law harmonization. It goes without saying that the analysis is equally relevant for the harmonization of other areas of private law.

The paper is organized as follows. Section 2 aims to show that even if the private law of separate jurisdictions facilitates economic activity as much as possible, the distributional consequences of private law may create a coordination problem as to the question of which private law to apply to an inter-jurisdictional agreement. Section 3 turns to a simple, static model in which to think about the issue of why a jurisdiction whose economy is less dependent upon the economies of other jurisdictions than the other way around might be in a position to apply leverage over the production of uniform private laws. Section 4 argues that a dynamic model will not overturn our conclusions. Why the division into default rules and mandatory rules in contract law is not relevant to the analysis as conducted in the previous sections is explained in Section 5. In the subsequent section our model serves as a basis for understanding the drive for harmonization of sales law on a global level in the twentieth century. The final section presents concluding remarks.

\section{Divergent private law}

Consider an installment contract between a buyer and a seller. The buyer is involved in the purchase of several items in sequence during some time interval. The buyer makes payments during the same time interval. Typically the total value of the purchases exceeds the aggregate payment for some time, i.e. some items have been delivered but not yet been paid for.

In case the buyer defaults, the seller will seek repossession of the items sold. Now there are two alternative legal arrangements concerning repossession. In the first arrangement, the seller has a claim against all items with an obligation to return the payments received, whereas in the second arrangement the seller may only repossess the items which have not yet been paid for. Conditional on signing the installment contract, the former arrangement is sellerbiased and the latter buyer-biased. It is also conceivable that a seller would only be willing to offer the installment contract under the proviso that all items can be repossessed in case of default. In that case both the seller and the buyer would prefer this legal solution to the alternative one. A risk-averse buyer on the other hand, might only be willing to accept the installment contract under the arrangement where only unpaid items can be repossessed.

The important point is the following. Even if both legal arrangements are efficient from an ex ante point of view, in the sense that they create the same expected surplus, the way this surplus is divided between the buyer and the seller is typically not the same. Both buyers and sellers are usually not indifferent between the case where all items are repossessed and payments received are returned and the case where only unpaid items are repossessed. The two legal solutions have therefore different distributional consequences. There are many other examples where distinct legal solutions are feasible, depending on for instance the legal provisions concerning transfer of property, liability for breach, remedies for breach, and burden of proof, with some parties preferring the one solution, and others the alternative.

The fact that private law has distributional consequences has been noted before in the literature (see, e.g. Baird, Gertner, \& Picker, 1994, p. 219; Cooter \& Ulen, 2003, p. 260; Shavell, 2004, pp. 652-654). Thus, different private laws that are efficient, i.e. maximize the expected potential gains to be reaped from economic activity, can have different distributional consequences. Throughout the paper it is assumed that separate jurisdictions do not randomize their choice of private law. That is to say, differences in the private law of separate jurisdictions are to be explained by pointing out that separate jurisdictions have genuinely differ-
Table 1

A two-player coordination game

\begin{tabular}{lll}
\hline A's strategy & \multicolumn{2}{l}{ B's strategy } \\
\cline { 2 - 3 } & $\mathrm{y}$ & $\mathrm{z}$ \\
\hline $\mathrm{y}$ & 1000,1500 & 0,0 \\
$\mathrm{z}$ & 0,0 & 1500,1000 \\
\hline
\end{tabular}

ent preferences regarding the way in which private law ought to affect the distribution of potential gains from economic activity. It follows that, to understand private law harmonization, an investigation of whether separate jurisdictions, constrained by economic rivalry, will succeed in providing private law that facilitates economic activity as much as possible does not suffice. The latter issue has received considerable scholarly attention (see, e.g. La Porta, López-de-Silanes, Pop-Eleches, \& Shleifer, 2004; Mahoney, 2001; Wagner, 1998 and references therein; Mattei, 1994).

In the case of inter-jurisdictional economic activity, there is a further element that contributes to the division of the surplus. A party involved in an inter-jurisdictional trade is better informed about its own private law than about the private law of the other jurisdiction. Each party would therefore prefer to apply the legal rules of its own jurisdiction over the legal rules of the other jurisdiction. A party incurs an additional transaction cost when the private law of the other jurisdiction is being used.

The issue of which private law to apply to an inter-jurisdictional sale of goods is captured by the two-player coordination game of Table 1. The two parties to the sale are labeled players $A$ and B. Player A is the seller and belongs to jurisdiction Y. Player B is the buyer and belongs to jurisdiction $Z$. Jurisdiction $Y$ has buyerbiased private law and jurisdiction $Z$ has seller-biased private law. The monetary value to the seller of using seller-biased private law is $\$ 1000$, the same as the monetary value to the buyer of using buyer-biased private law. Player $\mathrm{A}$ has a reservation price of $\$ 500$ under seller-biased private law, and $\$ 1500$ under buyerbiased private law. Player B's willingness to pay is $\$ 3500$ under seller-biased private law and $\$ 4500$ under buyer-biased private law. Moreover, when using the private law of the other jurisdiction, a player incurs a transaction cost of $\$ 500$. The contracting price equals $\$ 2500$.

For simplicity, assume that each party has a choice of only two strategies, 'application of private law of jurisdiction $Y$ ' and 'application of private law of jurisdiction $Z$ ', labeled $y$ and $z$ respectively. The numbers in the table represent the assumed payoffs, that is, the gains from economic activity, received by each player for each combination of strategies that could be chosen by the players. The left-hand number of a cell of this matrix is the payoff accruing to player A, the right-hand number that of player B.

The assumed payoffs reflect four things. First, the payoffs reflect that the sale of goods produces a total gain of $\$ 3000$. Second, the payoffs indicate that with a contracting price of $\$ 2500$, the total gain of $\$ 3000$ is not divided evenly amongst the players. This is because the division of the $\$ 3000$ surplus depends in part on the applicable substantive private law. Jurisdiction $Y$ has buyer-biased private law and jurisdiction $\mathrm{Z}$ has seller-biased private law. Third, the payoffs reflect that using private law of the other jurisdiction, both players incur a transaction cost of $\$ 500$. Then, application of the private law of jurisdiction $Z$ to the sale results in a payoff of $\$ 1500(\$ 2500-\$ 500-\$ 500)$ to player $A$ and a payoff of $\$ 1000$ ( $\$ 3500$ - \$2500) to player B. Conversely, application of the private law of jurisdiction $\mathrm{Y}$ to the sale results in a payoff of $\$ 1500$ ( $\$ 4500-\$ 2500-\$ 500)$ to player B and a payoff of $\$ 1000$ $(\$ 2500$ - $\$ 1500)$ to player A. Fourth, in case the players fail to subject their agreement to the private law of either jurisdiction, they 
are in disagreement as to material terms. This, in turn, means that the players have not formed a valid contract and the resulting payoff is $\$ 0$ to each player.

The resulting game belongs to a class of games known as coordination games. The game has two Nash equilibria in pure strategies, with action profiles $(y, y)$ and $(z, z)$ and with payoffs $(1000,1500)$ and $(1500,1000)$ respectively. This is to say that whilst parties might have a desire to enter into a mutually beneficial interjurisdictional agreement, they might fail in doing so because of incompatible views regarding the applicable private law.

Changes in the contracting price can solve the coordination problem caused by the distributional consequences of private law. But the informational asymmetry regarding the knowledge of unfamiliar private law, and the transaction costs involved in learning the monetary consequences of unfamiliar private law might prevent parties from making appropriate changes in the contracting price (see, e.g. Rubinstein, 1985).

\section{Uniform private law}

A uniform private law solves the coordination game in which parties engaged in inter-jurisdictional economic activity are embroiled. Supposing that private law of all jurisdictions facilitates economic activity as much as possible, as we do throughout the paper, any argument that the private law of a given jurisdiction ought to be placed into a uniform law because, as compared to the private law of other jurisdictions, this particular private law best facilitates economic activity is rendered meaningless. Then, which legal rules are likely to survive into the final draft of a successful uniform private law? In this respect, it is worth noting that Lazear (1999) builds a model on the assumption that individuals have incentives to learn other languages and cultures so as to create a larger pool of potential trading partners. Likewise, one can apply the assumption that separate jurisdictions have incentives to place the legal rules into uniform private laws of another jurisdiction so as to promote exports to and imports from this jurisdiction.

The effort of jurisdictions to compose a uniform law dealing with a particular branch of private law can again be captured by a game. This game is shown in Table 2 . The players in the game are jurisdictions $\mathrm{Y}$ and $\mathrm{Z}$. Regarding the composition of a uniform private law, each jurisdiction has a choice of two strategies, 'placing legal rules of jurisdiction $Y$ into a uniform private law' and 'placing legal rules of jurisdiction $\mathrm{Z}$ into a uniform private law', labelled $\mathrm{y}$ and $\mathrm{z}$ respectively.

The following assumptions are being made. It is assumed that the prevailing legal solutions in jurisdictions $\mathrm{Y}$ and $\mathrm{Z}$ facilitate (inter-jurisdictional) economic activity as much as possible and are assumed to be in accordance with the preferences of their respective citizens. Absent uniform private laws, due to disputes over which private law to apply to inter-jurisdictional legal problems, jurisdictions $\mathrm{Y}$ and $\mathrm{Z}$ may fail to reap potential gains from interjurisdictional economic activity. Thus, once the two jurisdictions have agreed to adopt the legal rules of either jurisdiction into a uniform private law, this leads to benefits with a net present value $\$ B$ to each of them. Note that this is true whichever way the uniform

\section{Table 2}

Costs and benefits of uniform private law

\begin{tabular}{lll}
\hline Y's strategy & \multicolumn{2}{l}{ Z's strategy } \\
\cline { 2 - 3 } & $\mathrm{y}$ & $\mathrm{z}$ \\
\hline $\mathrm{y}$ & $B, B-C_{\mathrm{z}}$ & $0,-C_{\mathrm{z}}$ \\
$\mathrm{z}$ & $-C_{\mathrm{y}}, 0$ & $B-C_{\mathrm{y}}, B$ \\
\hline
\end{tabular}

private law affects the distribution of potential gains from economic activity.

On the other hand, in adopting legal rules of jurisdiction $Y$ into a uniform private law, jurisdiction $\mathrm{Z}$ will have to bear two different types of costs. The same holds true the other way around. That is, the transaction costs of learning unfamiliar legal solutions. This has been noted before in the literature (see e.g. Ott and Schäfer, 2004, p. 294). ${ }^{4}$ Also, the costs of applying less-preferred legal solutions. These costs arise because, as noted in Section 2, it is assumed in this paper that separate jurisdictions have not randomized their choice of private law. The law and economics literature on harmonization of private law has thus far paid little attention to these latter costs. We denote by $C_{\mathrm{y}}$ the net present value of the costs incurred by jurisdiction $Y$ in adopting legal rules of jurisdiction $Z$ into a uniform private law. And by $C_{z}$ we denote the net present value of the costs incurred by jurisdiction $\mathrm{Z}$ in adopting legal rules of jurisdiction $\mathrm{Y}$ into a uniform private law. The resulting game is the following.

Three basic game-theoretical structures can arise: in Case 1 each jurisdiction finds that the extra costs incurred in adopting the legal rules of any other jurisdiction into a uniform private law exceed the extra benefits obtained. Of course, in this instance, any plan to unify this segment of private law can only be thwarted by the jurisdictions involved; in Case 2 the one jurisdiction finds that the extra costs incurred in adopting the legal rules of the other jurisdiction into a uniform private law exceed the extra benefits obtained. However, the same does not hold the other way around. In this instance, to reduce legal impediments for inter-jurisdictional economic activity, this will force the one jurisdiction to agree with the adoption of the legal rules of the other jurisdiction into a uniform private law; in Case 3 each jurisdiction finds that the extra costs incurred in adopting the legal rules of the other jurisdiction into a uniform private law do not exceed the extra benefits obtained. The same holds the other way around. This game-theoretical structure corresponds with a coordination game. The game has two Nash equilibria in pure strategies, $(y, y)$ and $(z, z)$. Nash equilibrium (y, $\mathrm{y})$ leads to payoffs $\left(B, B-C_{\mathrm{z}}\right)$ and Nash equilibrium $(\mathrm{z}, \mathrm{z})$ to payoffs $\left(B-C_{\mathrm{y}}, B\right)$. Accordingly, jurisdiction Y prefers the former Nash equilibrium and jurisdiction $Z$ the latter. The Nash equilibria are not Pareto ranked. In this case, negotiations on the adoption of a uniform private law are fraught with difficulties and it is far from evident which jurisdiction will give in first.

If one would have to make a prediction on the outcome of the game in this case, it would be natural to use the concept of risk dominance as introduced in Harsanyi and Selten (1988). The idea behind the concept of risk dominance is to recognize that the existence of strategic uncertainty, arising from the fact that there are two Nash equilibria in pure strategies, creates an element of risk in jurisdictions' choices. This risk is present since the one jurisdiction does not know for sure what the other will do. According to Harsanyi and Selten (1988), jurisdiction Y's risk situation is connected to the ratio $\left(B+C_{\mathrm{y}}\right) /\left(B-C_{\mathrm{y}}\right)$. The numerator in this ratio corresponds to the loss in payoffs to jurisdiction $Y$ when moving from the upper-left cell to the lower-left cell. That is, when jurisdiction Y does not play according to Nash equilibrium $(y, y)$ but deviates to $z$. Similarly, the denominator in this ratio corresponds to the loss in payoffs to jurisdiction $Y$ when moving from the lower-right cell to the upper-right cell. That is, when jurisdiction Y does not play according to Nash equilibrium $(z, z)$, but deviates to $y$. The higher the ratio, the more attractive it is for jurisdiction $\mathrm{Y}$ to coordinate on Nash equilibrium $(\mathrm{y}, \mathrm{y})$.

\footnotetext{
${ }^{4}$ The transaction costs of learning unfamiliar legal solutions are exogenous in our model. In their model of harmonization of legal regimes, Carbonara and Parisi (2007) endogenize these transaction costs.
} 
Analogously, jurisdiction Z's risk situation is connected to the ratio $\left(B+C_{\mathrm{z}}\right) /\left(B-C_{\mathrm{z}}\right)$. The higher this ratio, the more attractive it is for jurisdiction $Z$ to coordinate on Nash equilibrium $(z, z)$. If $\left(B+C_{\mathrm{y}}\right) /\left(B-C_{\mathrm{y}}\right)$ exceeds $\left(B+C_{\mathrm{z}}\right) /\left(B-C_{\mathrm{z}}\right)$, then jurisdiction $Z$ 's reason to abide by its own legal rules rather than the legal rules of jurisdiction $Y$ is stronger than jurisdiction Y's reason to abide by its own legal rules rather than by the legal rules of jurisdiction $Z$. After some manipulations, it can be verified that this is the case if and only if $C_{\mathrm{y}}>C_{\mathrm{z}}$.

The costs of learning the private law of jurisdiction $\mathrm{Z}$ are not higher to a citizen of jurisdiction $\mathrm{Y}$, because it is a relatively slow learner. Rather, information on economic interdependencies between separate jurisdictions offers a clue as to why $C_{\mathrm{y}}>C_{\mathrm{z}}$. Supposing that the total value of economic activity of jurisdiction $Y$ is higher than the total value of economic activity of jurisdiction $Z$, economic activity with jurisdiction $Y$ will constitute a relatively larger share of jurisdiction Z's total economic activity than the other way around. As inter-jurisdictional economic activity is relatively more important to jurisdiction $\mathrm{Z}$ than to jurisdiction $\mathrm{Y}$, jurisdiction $Z$ will face lower switching costs than jurisdiction $Y$. It is therefore that we argue that when the private law of all jurisdictions facilitates economic activity as much as possible, the jurisdiction the economy of which is relatively less dependent upon the economies of other jurisdictions than vice versa will see its own legal rules introduced into uniform private laws, leading to the first best outcome from this jurisdiction's perspective.

\section{Dynamic perspective}

Thus far, the analysis has been completely static. The point that developments in private law should be studied from a dynamic perspective is well-taken. In this case the situation should be modeled as an infinite-horizon multi-stage game. In each period jurisdictions choose which legal rules to adopt into uniform private laws. At the end of each period, jurisdictions observe the period's action profile. The history at a period is determined by the sequence of actions in the previous periods. A pure strategy for a jurisdiction in game-theoretic terms is simply a contingent plan of adoption of legal rules into uniform private laws for each possible history.

The simplest case would be as follows. Whenever jurisdictions $\mathrm{Y}$ and $\mathrm{Z}$ agree on adopting the legal rules of either jurisdiction into uniform private laws, this would lead to instantaneous benefits \$B to each of them. Otherwise, benefits are 0 . The costs of switching from any set of legal rules to a different set of legal rules are assumed to be $C_{\mathrm{y}}$ for jurisdiction $\mathrm{Y}$ and $C_{\mathrm{z}}$ for jurisdiction $\mathrm{Z}$. Then, instantaneous payoffs in the first period are as indicated in Table 2. Instantaneous payoffs would coincide with those in Table 2 in any period where the legal solutions chosen by the jurisdictions coincide with those in the first period. Instantaneous payoffs in a period where in the previous period jurisdictions have coordinated on the original legal rules of jurisdiction Y are depicted in Table 3.

A similarly looking table applies to those periods where jurisdictions have coordinated on the original legal rules of jurisdiction $\mathrm{Z}$ in the period before. The instantaneous payoffs in a period where in the previous period jurisdiction $Y$ has chosen the original legal rules of jurisdiction $Z$ and jurisdiction $Z$ the original legal rules of jurisdic-

Table 3

Costs and benefits of uniform private law

\begin{tabular}{lll}
\hline Y's strategy & \multicolumn{2}{l}{ Z's strategy } \\
\cline { 2 - 3 } & $\mathrm{y}$ & $\mathrm{z}$ \\
\hline $\mathrm{y}$ & $B, B$ & $0,-C_{\mathrm{z}}$ \\
$\mathrm{z}$ & $-C_{\mathrm{y}}, 0$ & $B-C_{\mathrm{y}}, B-C_{\mathrm{z}}$ \\
\hline
\end{tabular}

tion $\mathrm{Y}$ are similar to those in Table 2. Total payoffs are determined as the discounted sum of instantaneous payoffs.

It can be shown that a dynamic analysis of the situation at hand does not change the conclusions reached in our static analysis in the following sense. Not switching after any history is a dynamic Nash equilibrium in Case 1 . Then, no harmonization of private law will ever take place. In Case 2, the following pair of strategies constitutes a dynamic Nash equilibrium. The jurisdiction that is not able to recover costs involved in a change does never switch. The other jurisdiction switches and adopts private law of the high costs jurisdiction. It does not switch anymore once harmonization of private law has taken place. As before, this forces the low costs jurisdiction to adopt the legal rules of the other jurisdiction immediately. When both jurisdictions would recover the costs suffered in adopting the other jurisdiction's legal rules into a uniform private law, Case 3, both the situation where both jurisdictions coordinate on the legal rules of jurisdiction $\mathrm{Y}$ and the situation where both jurisdictions coordinate on the legal rules of jurisdiction $\mathrm{Z}$ can be sustained as Nash equilibria. In the former case, Nash equilibrium strategies would be as follows. Jurisdictions $\mathrm{Y}$ and $\mathrm{Z}$ both do not switch whenever harmonization of private law has taken place, and choose y otherwise. In the latter case, Nash equilibrium strategies would be such that jurisdictions $Y$ and $Z$ both do not switch whenever harmonization of private law has taken place, and choose $\mathrm{z}$ otherwise. As before, the Nash equilibria are not Pareto ranked and negotiations on the adoption of a uniform private law are fraught with difficulties.

\section{Default rules and mandatory rules}

Private law can be divided into two kinds of rules: default rules and mandatory rules. ${ }^{5}$ Whereas parties can contract around default rules, mandatory rules are enforced, even if the parties to a contract attempt to override or modify them. The subdivision is not relevant to our analysis because mandatory rules as well as default rules have distributional consequences. This calls for a brief explanation. Default rules allow for parties to provide the terms of an agreement by submitting their own (standard) forms. But, like default rules, standard forms affect the way potential gains from economic activity are divided. Von Mehren (1990, p. 267) puts it thus: '(...) the parties' posture in "battle-of-the-forms" cases; they want a contract but, with respect to certain issues of importance, each wishes to contract on the terms he proposed.' The resulting "battle of the forms" can be captured by a two-player coordination game similar to the one presented in Table 1 . To resolve battles of the forms, courts draw on default rules, amongst other sources. It goes without saying that at least one contracting party will judge the default rules that govern the unresolved battle of the forms unfavorably as compared to its own standard form.

On the other hand, upon enactment of a uniform private law, the increase in inter-jurisdictional economic activity of the jurisdictions involved is in part dependent on the branch of private law under consideration. For example, movements for harmonization of family law will perhaps draw little support from separate jurisdictions, not so much because of the distributional consequences of domestically defined family law, but because of the relatively limited number of inter-jurisdictional family disputes. In contrast, in spite of the potentially large distributional consequences of, for example, domestically defined commercial law, initiatives to unify this field may nonetheless resonate well with separate jurisdictions. The total value of inter-jurisdictional commercial

\footnotetext{
5 Default rules are sometimes called suppletive rules or background rules and mandatory rules are sometimes called immutable rules or regulations.
} 
transactions may fuel calls for unity. At any rate, the recognition that harmonization of both mandatory rules and default rules in contract law leads to coordination problems provides a sober antidote to the argument that harmonization of default rules (e.g. commercial law) poses less of a challenge than harmonization of mandatory rules (e.g. family law). Much has been made of this argument in the legal literature (see, e.g. Ogus, 1999, pp. 410-412; Garoupa \& Ogus, 2006, pp. 341-342). Nevertheless, incompatible views of separate jurisdictions regarding the way in which (default) private law rules ought to affect the distribution of potential gains from economic activity can form an insurmountable obstacle to the production of uniform private laws. That separate jurisdictions might actually fail in composing a successful uniform law dealing with cross-border commercial transactions is evidenced in the next section.

\section{An illustration}

As can be gathered from the preceding sections, the emergence of a global private law cannot be understood through examining the fruits of comparative legal scholarship alone. Information on economic interdependencies between separate jurisdictions needs to be infused in the investigation, too. An example serves to illustrate this point. All EU Member States but Portugal, Ireland and Great Britain have endorsed the United Nations Convention on Contracts for the International Sale of Goods (CISG) (Vienna, 1980). And numerous other countries across the globe, including the United States, have become Contracting States. ${ }^{6}$

Various commentators have noted that the drafting process of the successful CISG (Vienna, 1980) was in no small part influenced by the United States (US) (see, e.g. Landau, 1984, p. 35). And have also noted that the US had hardly - if at all - influenced the drafting process of the abortive Uniform Law on the International Sale of Goods (ULIS) (The Hague, 1964) and the Uniform Law on the Formation of Contracts for the International Sale of Goods (ULFIS) (The Hague, 1964) (see, e.g. Honnold, 1979, p. 225). Unsurprisingly, then, that the US had declined to endorse the ULIS (The Hague, 1964) and the ULFIS (The Hague, 1964).

But does a country's choice for the CISG (Vienna, 1980) automatically imply that this country prefers the sales law as embodied in the CISG (Vienna, 1980) to any other sales law? If only because the formal sphere of application of the CISG (Vienna, 1980) is, in principle, limited to the international, that is, cross-border, sale of goods, the answer to this question is not self-evident. Indeed, to limit the formal sphere of application of the CISG (Vienna, 1980) to the international sale of goods is to allow contracting states to apply different sales law to the sale of goods performed within their own confines.

In view of the analysis as conducted in Section 3, this paper holds that even though countries might really have preferred their own sales law, they might still have had an interest in implementing the CISG (Vienna, 1980). This is for the following reason. After the Second World War, the US had decisively dethroned Britain as the largest trading partner of the world. Now, given the relative economic dependence of other countries upon the US, lifting legal barriers to international economic activity, although important to all countries, became relatively less important to the US than to other countries. This then gave the US increased leverage to press for adoption of 'American' sales law into the CISG (Vienna, 1980). On the other hand, had Western Europe, in particular, in defiance of American disinterest in the whole venture, succeeded in unifying

\footnotetext{
${ }^{6}$ For a complete list of the Contracting States to the CISG (Vienna, 1980) the interested reader might refer to a website maintained by the United Nations: http://www.uncitral.org/.
}

its nationally defined sales laws by means of the ULIS (The Hague, 1964) and the ULFIS (The Hague, 1964), this would have put countries in this corner of the globe under less strain to enact the CISG (Vienna, 1980). Lacking a unified stand in matters of commercial law, Western Europe had weakened its position to fend off pressure from the US to use the American Uniform Commercial Code - Article 2 on Sales as principal guideline for the CISG (Vienna, 1980). As to the question of why Britain, in particular, has, thus far, declined enactment of the CISG (Vienna, 1980), it pays to notice that the City of London has remained a centre for the resolution of international commercial disputes to this very day. British lawyers clearly have a comparative advantage if British law is applied instead of the CISG. Britain's dominant share in world trade until the Second World War must have helped London become a centre for the resolution of international commercial disputes.

Two lessons can be learned from the harmonization of sales law on a global level for future harmonization of other segments of private law on a global level. First of all, it must be emphasized that international sales law has been harmonized by means of a convention. As adoption of the CISG (Vienna, 1980) remained the prerogative of national governments, the movement for global harmonization of sales law did not in any way infringe on the legal sovereignty of the jurisdictions involved. Accordingly, without intervention by supranational institutions, the CISG (Vienna, 1980) brought unity in an area of private law where it was, at least according to the Contracting States, really needed. This approach looks equally promising for the harmonization of other areas of private law on a global level.

As an aside, mention should be made of the 'Joint Network on European Private Law' established as of 1 May 2005. This so-called Network of Excellence is part of the Sixth Framework Programme of the European Commission. Its principal goal is to deliver a proposal for the "Common Frame of Reference" for European contract law as described in the Commission's Action Plan on Contract Law (COM [2003] 68 final) and its follow-up Communication COM (2004) 651 final. $^{7}$ The proposal will be presented in the form of principles ("Common Principles of European Contract Law" = CoPECL), including definitions, general concepts and legal rules. In Annex I "Description of Work" of the Contract between the European Commission and the participants of the Network on European Private Law it is stated that (p. 5): '(...) the CoPECL may inspire further reflection on an optional new Community instrument.' This idea of the European Commission comes in for the following (critical) question. Might EU Member States that are truly bent on establishing unity in their nationally defined private laws succeed in achieving their goal by means of international conventions like the CISG (Vienna, 1980)? If the number of Contracting States to the CISG (Vienna, 1980) is any guide, the answer is unequivocally yes. This, in turn, means that the employment of Community instruments to harmonize areas of private law in the EU would violate the so-called principle of subsidiarity, as enshrined in Article 5 of the European Union Treaty. ${ }^{8}$

The second lesson to be learned is that the US' leverage over the production of the CISG (Vienna, 1980) indicates that a link can be identified between, on the one hand, economic interdependencies between separate jurisdictions and, on the other, developments in the field of private law. The ensuing elaboration purports to offer

\footnotetext{
7 Information on the European Commission's Action Plan on a More Coherent Contract Law can be obtained from the following website: http://europa.eu. int/comm/consumers/.

${ }^{8}$ An investigation of the allocation of competence between the EU Member States and the European Commission has also been conducted in the field of competition law (van den Bergh, 1996), for example. See also Kerber and Grundmann (2006).
} 
an indication of how economic interdependencies between separate jurisdictions might affect processes of unifying domestically defined private law. Deep legal rifts are traditionally said to be found in the private law of England and the national private law on the European continent. Kinship among the national private law on the European continent is thought to be relatively stronger. Hence, comparative legal research supports the view that any project aimed at unifying (parts of) the private law of the EU Member States will face the challenge of assimilating the private law of England with the national private law of continental Europe (see, e.g. Reid \& Zimmermann, 2000; Zimmermann, Reid, \& Visser, 2005).

In order to evaluate this view, it is important to note, for one thing, that disparities in national private law within the EU may sometimes be at least as sharp as any between the US and the members of the EU themselves. Insofar as adoption of a uniform private law is concerned, it may, thus, make little difference to EU Member States whether they adopt a uniform law largely based on the private law of another Member State, or, for that matter, adopt a uniform law largely based on American private law. For another, taking economic interdependencies between jurisdictions into account, to end any harmonization project within the EU successfully, Franco-German approval ought perhaps to be regarded as essential. However, the EU and the US are each other's most important source and destination for trade and capital flows. Upon this observation, adoption of a uniform private law largely inspired by American examples would be to strike two birds with one blow for EU Member States. Impediments to inter-jurisdictional economic activity are swept away within the EU and, simultaneously, between the Union and her most important economic partner the US. Especially when the EU turns out to be deeply divided about matters of private law, her Member States look prone to submit to pressure from the US to place the legal rules it promotes into uniform private laws.

\section{Concluding remarks}

This paper shows that to explain campaigns for a more unified private law on a global level, comparative legal scholarship is but an ingredient of a larger study that should also comprise an analysis of economic interdependencies between separate jurisdictions. Unity in the private law of separate jurisdictions might perhaps help to sweep away some of the many legal obstacles that stand in the way of inter-jurisdictional economic activity. However, even when separate jurisdictions subscribe to the aim of unifying (branches of) domestically defined private law, they are unlikely to read from precisely the same play sheet. This is because separate jurisdictions might have genuinely different preferences regarding alternative legal arrangements. We have argued that this opens the way for coordination problems to emerge between separate jurisdictions about the issue of which legal rules to place into uniform private laws. As to the question of which jurisdiction might be in a position to apply influence over the production of uniform private laws, this paper held that economic interdependencies between separate jurisdictions provide an answer. A jurisdiction the economy of which is relatively less dependent upon the economies of other jurisdictions than the other way around has an advantage over other jurisdictions. This advantage may result in the introduction of the legal rules of that jurisdiction into uniform private laws. For, in doing so, other jurisdictions would most encourage their own economic activity. Then again, for all extra benefits from interjurisdictional economic activity created by uniform private laws, due to coordination problems, jurisdictions might nonetheless fail to enact uniform private laws.

Furthermore, this paper sought to interpret empirical observations against the theoretical arguments as advanced. Comparative legal scholars have observed that the United States exercised profound influence over the drafting process of the successful United Nations Convention on Contracts for the International Sale of Goods (CISG) (Vienna, 1980). Did American sales laws find their way into the CISG (Vienna, 1980) because, as compared to other sales laws, they apparently best facilitated economic activity? Possibly so, but this line of reasoning - if implicitly - rests on the premise that sales law that facilitates economic activity as much as possible can only affect the distribution of potential gains from economic activity in a unique way. Instead, since sales law that facilitates economic activity as much as possible need not have the same distributional consequences, the reason for America's substantial influence over the drafting process of the CISG (Vienna, 1980) is something subtler. America's economic clout after the Second World War must have increased the countries' ability to influence the drafting process of a projected uniform sales law. The point is that, given the relative economic dependence of other countries upon the US, the removal of legal roadblocks to international economic activity, although increasingly important to all countries, was relatively less important to the US than to other countries. Thus, to promote exports to and imports from the United States, other countries had an interest in composing a uniform sales law along American lines. On the other hand, as countries were perfectly allowed to decline enactment of the CISG (Vienna, 1980), the trend towards global harmonization of sales law did not in any way compromise the legal sovereignty of the countries involved. Regarding the harmonization of other areas of private law, this leads to the following policy implication: when international conventions in the field of private law fail to garner widespread support, any offer by supranational institutions to come to the rescue should be treated with the utmost skepticism.

\section{Acknowledgements}

The authors would like to thank two anonymous referees for helpful comments and suggestions.

\section{References}

Baird, D. G., Gertner, R. H., \& Picker, R. C. (1994). Game theory and the law. Cambridge, MA: Harvard University Press.

van den Bergh, R. (1996). Economic criteria for applying the subsidiarity principle in the European Community: The case of competition policy. International Review of Law and Economics, 16, 363-383.

Carbonara, E., \& Parisi, F. (2007). The paradox of legal harmonization. Public Choice, 132, 367-400.

Cooter, R., \& Ulen, T. (2003). Law and economics (4th ed.). USA: Addison Wesley, Longman.

Garoupa, N., \& Ogus, A. (2006). A strategic interpretation of legal transplants. Journal of Legal Studies, 35, 339-363.

Harsanyi, J. C., \& Selten, R. (1988). A general theory of equilibrium selection in games. Cambridge, MA: MIT Press

Honnold, J. O. (1979). The draft convention on contracts for the international sale of goods: An overview. American Journal of Comparative Law, 27, 223-230.

Kerber, W., \& Grundmann, S. (2006). An optional European Contract Law Code: Advantages and disadvantages. European Journal of Law and Economics, 21, 215-236.

Landau, H. L. (1984). Background to U.S. participation in United Nations Convention on contracts for the international sale of goods. The International Lawyer, 18, 29-35.

La Porta, R., López-de-Silanes, F., Pop-Eleches, C., \& Shleifer, A. (2004). Judicial checks and balances. Journal of Political Economy, 112, 445-470.

Lazear, E. P. (1999). Culture and language. Journal of Political Economy, 107, S95-S126.

Mahoney, P. G. (2001). The common law and economic growth: Hayek might be right. Journal of Legal Studies, 30, 503-525.

Mattei, U. (1994). Efficiency in legal transplants: An essay in comparative law and economics. International Review of Law and Economics, 14, 3-19.

von Mehren, A. T. (1990). The battle of the forms: A comparative view. American Journal of Comparative Law, 38, 265-298.

Ogus, A. (1999). Competition between national legal systems: A contribution of economic analysis to comparative law. International and Comparative Law Quarterly, $48,405-418$ 
Ott, C., \& Schäfer, H.-B. (2004). The economic analysis of civil law. Cheltenham, UK: Edward Elgar Publishing.

Reid, K., \& Zimmermann, R. (2000). The development of legal doctrine in a mixed legal system. In K. Reid \& R. Zimmerman (Eds.), A history of private law in Scotland (pp. 1-13). Oxford: Oxford University Press.

Rubinstein, A. (1985). A bargaining model with incomplete information about time preferences. Econometrica, 53, 1151-1172.

Shavell, S. (2004). Foundations of economic analysis of law. Cambridge, MA: Harvard University Press.
Smits, J. M. (2001). Introduction: Mixed legal systems and European private law. In J. Smits (Ed.), Ius Commune Europaeum series: Vol. 36. The contribution of mixed legal systems to European private law (pp. 1-13). Antwerp: Intersentia.

Wagner, R. E. (1998). Common law, statute law and economic efficiency. In P. Newman (Ed.), The new Palgrave dictionary of economics and the law (pp. 313-317). London: Macmillan Reference Limited.

Zimmermann, R., Reid, R., \& Visser, D. (Eds.). (2005). Mixed legal systems in comparative perspective-Property and obligations in Scotland and South Africa. Oxford: Oxford University Press. 